УДК 656.212

Канд. техн. наук. П.В. Долгополов, Ю.В. Алтухова, Д.В. Черепков

\title{
РОЗРОБЛЕННЯ ФУНКЦІОНАЛЬНИХ ЗАДАЧ ЗАЛІЗНИЧНИХ СИСТЕМ ДИСПЕТЧЕРСЬКОГО УПРАВЛІННЯ ІЗ ЗАСТОСУВАННЯМ ТЕОРІЇ РОЗКЛАДІВ
}

\author{
Представив д-р техн. наук, професор А.М. Котенко
}

Вступ і актуальність теми. Ефективність залізничних перевезень залежить від якості вирішення цілого ряду складних експлуатаційних задач на різних організаційних рівнях. Однією 3 таких задач $\epsilon$ організація поїздопотоків на залізничних дільницях та у вузлах.

Задача полягає у визначенні оптимального порядку прямування множини вантажних, пасажирських, господарських та інших поїздів в умовах обмежень, що визначені колійним розвитком полігона, в оперативному режимі.

Поставлена задача набуває особливої актуальності в умовах концентрації вантажного руху на окремих напрямках, що $\epsilon$ необхідним для розвитку швидкісного пасажирського руху. Крім того, за даними 
економічних експертів, у найближчі роки спостерігатиметься зростання вантажообігу на вітчизняному залізничному транспорті на рівні близько 3 \% на рік, що збільшить навантаження на «вузькі місця» залізничної мережі, зокрема на залізничні вузли.

Постановка проблеми. Одними із основних напрямків удосконалення організації транспортного процесу залізничного вузла $є$ забезпечення оптимізації процесів координації роботи взаємодії різних видів транспорту, раціонального розподілу між ними обсягів перевезень, своєчасного формування необхідних управлінських рішень. Вирішення цієї наукової задачі можливо здійснити шляхом упровадження логістичних принципів в усі ланки перевізного процесу залізничного вузла [1-3].

Процес формування логістичних технологій організації транспортного процесу залізничного вузла повинен носити комплексний характер і сприяти процесам реформування, враховувати інтереси всіх учасників перевізного процесу, бути спрямованим на ресурсозберігаючі технології при використанні обмежених ресурсів (рухомого складу, вантажних механізмів тощо), на покращення кількісних і якісних показників експлуатаційної роботи, на виконання та скорочення доставки вантажів, максимального задоволення вимог вантажовласників.

3 цією метою у даній статті базовий залізничний вузол розглянуто як єдину синергетичну систему [3], технологія роботи якої передбачає збільшення сумарного ефекту відносно суми окремих ефектів кожної з її підсистем (рис. 1).

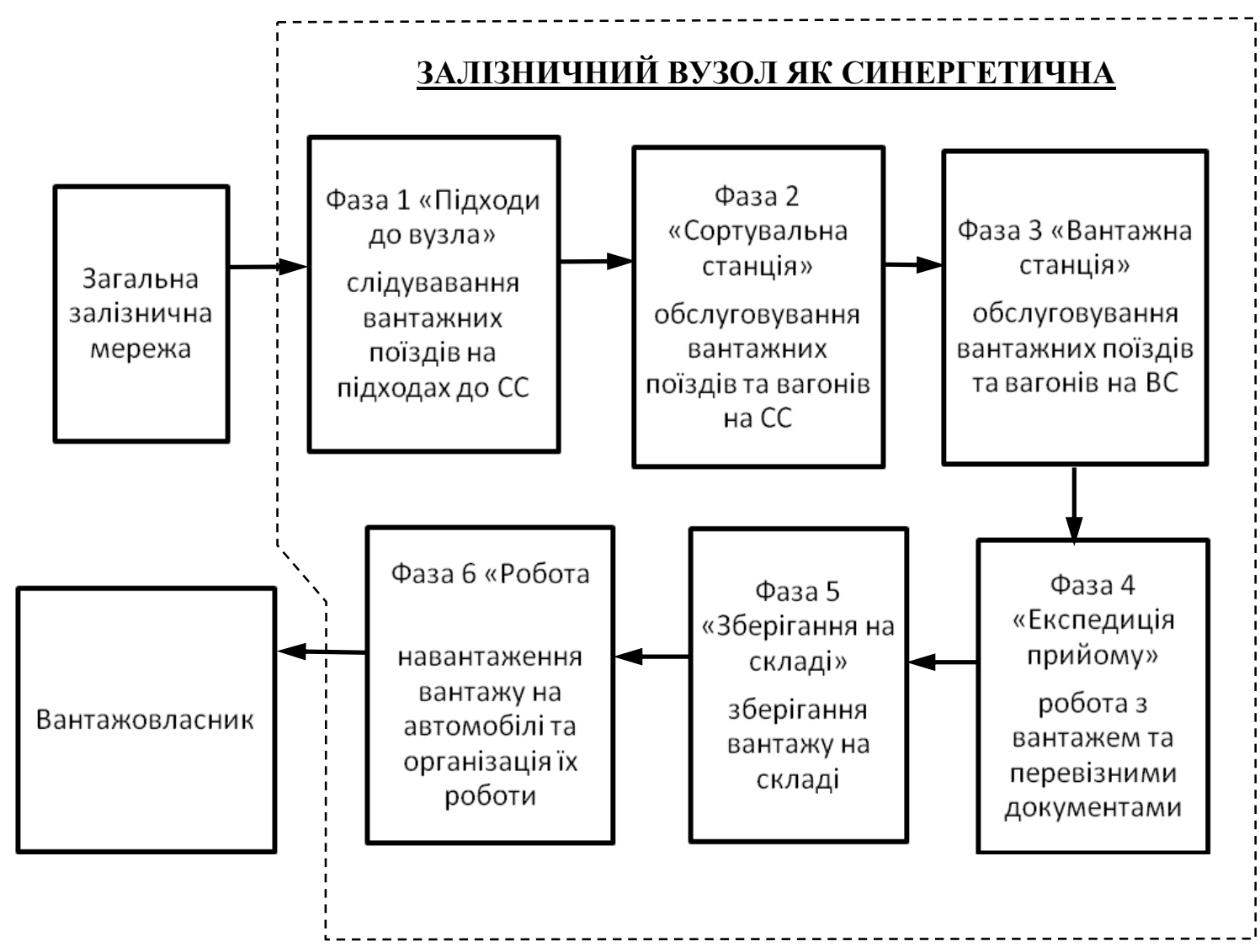

Рис. 1. Подання залізничного вузла як синергетичної системи 
Таким чином, метою статті $\epsilon$ вирішення задачі удосконалення роботи залізничного вузла як синергетичної системи на основі раціонального диспетчерського керівництва поїздопотоками, а також оптимізації роботи 3 клієнтами на вантажних станціях шляхом визначення зручного графіка подавання вагонів на вантажні фронти та організації руху автотранспорту клієнтів залізниці.

Основний зміст дослідження. При дослідженнях виявлено численні затримки поїздів у залізничних вузлах. Причому серед причин насамперед виступають:

- обмежена пропускна спроможність сортувальних станцій (СС) та підходів до них внаслідок скорочення колійного розвитку та його невідповідності сучасним напрямкам та розмірам поїздопотоків у вузлах;

- недосконалість

графіка руху поїздів (ГРП);

- непередбачені нормативним ГРП додаткові поїзди, поїзди, що запізнюються, а також ремонтні роботи на підходах тощо [2]. Дані фактори значно ускладнюють визначення оптимального плану обслуговування поїздів у вузлі, особливо коли це виконується особисто поїзним диспетчером (ДНЦ) на власний розсуд.

На основі аналізу існуючих математичних апаратів виявлено, що для побудови оптимізаційної моделі підведення поїздів до СС, що мають декілька підходів, доцільно використовувати математичний апарат теорії розкладів.

Як зазначено у статті [3], будь-яка робота 3 проходження поїзда може виконуватися будь-яким обслуговуючим пристроєм у відповідному технологічному ланцюзі (маршруті прямування поїзда), тобто всі пристрої можна вважати ідентичними.

Встановлено, що у такій системі, як «залізничний вузол» особливості технології проходження поїздів по елементах вимагають паралельно-послідовного з`єднання елементів обслуговування.
Якщо поїзд $x$ надходить на елемент $A$ у момент часу $t_{x A}$, то момент часу його надходження на елемент $B$ набуває значення

$$
t_{B} \geq t_{x A}+\xi_{x}, \text { де } \xi_{x} \geq 0
$$

Також необхідно задати мінімально можливі проміжки часу $\delta_{x i}^{A} \geq 0$ та $\delta_{x i}^{B} \geq 0$ між моментами часу початку надходження поїздів $x$ та $y$ на елементи відповідно $A$ та $B$ за умови, що поїзд $x$ надходить раніше, ніж $y$.

Позначимо через $\tau_{x A} \geq 0$ та $\tau_{x B} \geq 0$ моменти часу, раніше яких не може бути розпочато надходження поїзда $k$ на елементи відповідно $A$ та $B$.

$$
\begin{array}{ccrr}
\text { Однак } & \text { у } & \text { випадку, } & \text { якщо } \\
\xi_{x}=\delta_{x i}^{A}=t_{x A}, & \delta_{x i}^{B}=t_{x B} & \text { та } \\
\tau_{x A}=\tau_{x B}=0, & x, y=\overline{1, n}, \quad \text { то } & \text { задачу }
\end{array}
$$
побудови оптимального розкладу пропуску поїздів у залізничному вузлі у напрямку сортувальної станції доцільно подати як знаходження такої перестановки $\pi$, якій відповідає найменше значення

$$
d_{b}(\pi)=\max _{1 \leq k \leq n}\left(\sum_{x=1}^{k} t_{x A_{i}}-\sum_{x=1}^{k-1} t_{x B_{i}}\right)
$$

де $\pi$ - початкова послідовність надходження поїздів на елемент $A$ залізничного вузла, $\pi=\left(i_{1}, i_{2}, \ldots, i_{n}\right)$. Послідовність надходження поїздів на елемент $B$ задано як $\pi `=\left(j_{1}, j_{2}, \ldots, j_{n}\right)$.

Оскільки на одній блок-дільниці, так само, як і на одній колії станції, може перебувати не більше одного поїзда, то стає дійсною така важлива умова: на будь-який елемент залізничного вузла ( $A, B$ та інші) поїзд 1 (операція $i_{1}$ ) може надійти у момент часу $d=0$, а поїзд $x$ (операція $i_{x}$ ) - тільки після звільнення поїздом $x$-1 (операція $i_{x-1}$ ), $x=\overline{2, n}$ даного елемента [3,4]. 
Операцію $i_{1}$ на елементі $A$ може бути розпочато у момент часу $t_{i A_{1}}=\tau_{i A_{1}}$, операцію $i_{2} \quad-\quad$ у момент часу $t_{i A_{2}}=\max \left(\tau_{i A_{2}}, t_{i A_{1}}+\delta_{i_{1} i_{2}}^{A}\right)$ тощо. Таким чином, для мінімальної затримки через ворожість маршрутів прямування поїздів операція $i_{n}$ повинна бути розпочата у момент часу, який доцільно визначити як

$$
t_{i A_{n}}=\max \left(\tau_{i A_{n}}, t_{i A_{1}}+\delta_{i_{1} i_{n}}^{A}, \ldots, t_{i_{n-1}}+\delta_{i_{n-1} i_{n}}^{A}\right) .
$$

У вантажних поїздах прямують також і місцеві вагони, тому для створення більш прийнятного для вантажовласників графіка надходження місцевих вагонів на вантажні станції доцільно удосконалити графік руху передаточних поїздів. При цьому необхідно орієнтуватися на їх розрахункову кількість, що визначено за виразом

$$
n_{p}=0,5 \cdot \frac{N_{m z x}}{m_{\text {onm }}} \cdot\left(1+\kappa_{H}\right)
$$

де $\kappa_{H}-$ коефіцієнт внутрішньомісячної нерівномірності руху, $\kappa_{H}=1,15$;

$m_{\text {onm- }}$ оптимальне число вагонів у складі передаточного поїзда, ваг.

Оскільки передаточні поїзди фактично обертаються зі змінною величиною поїзда, то оптимальна кількість вагонів в составі визначена за мінімумом витрат на локомотиво- і вагоно-години [2] як

$$
m_{\text {onm }}=\sqrt{\frac{\left(2 \cdot L+V \cdot \sum t_{c m}\right) \cdot N_{\max } \cdot e_{л u}}{24 \cdot V \cdot e_{л u}}}
$$

де $L$ - довжина перегону між сортувальною і вантажною станціями, км;

$V$ - середня швидкість руху передаточних поїздів, км/год;

$t_{c m} \quad-\quad$ тривалість перебування локомотива на сортувальній i вантажній станціях за час одного обороту, год;

$$
\begin{aligned}
& e_{л ч}-\text { вартість локомотиво-години, грн; } \\
& e_{6 ч}-\text { вартість вагоно-години, грн. }
\end{aligned}
$$

\section{Результати}

моделювання оптимального плану обслуговування поїздів у залізничному вузлі запропоновано виводити на АРМ ДНЦ на основі мікропроцесорної системи диспетчерської централізації (МСДЦ) «Каскад» (рис. 2). Bci прогнозні нитки поїздів позначено на ГРП пунктирними лініями.

На даному ГРП ДНЦ має можливість корегувати прогнозні нитки по осі часу. При цьому при кожному корегуванні окремої нитки система оперативно корегує весь прогнозний ГРП із урахуванням умов безпеки руху поїздів [5].

Для визначення пріоритету подавання тієї чи іншої групи вагонів у роботі фактори, які впливають на першочерговість подавання-забирання вагонів: вагонів;

- тривалість подавання-забирання

- кількість вагонів у подачі;

- терміновість доставки вантажу:

- зайнятість вантажних фронтів (ВФ);

- незапланована зупинка розвантажувального комплексу.

Як додаткову послугу для вантажовласників необхідно ввести показник точного часу подавання вагонів на ВФ, які для кожного ВФ доцільно визначити як

$$
T^{\prime}=t_{n n}+t_{\text {розф }}^{\text {очік }}+t_{\text {розф }}+t_{\text {нак }}+t_{\text {под }}^{\text {очік }}+t_{\text {под }},
$$


де $t_{n n}-$ час знаходження вагонів у парку прибуття;

$$
t_{\text {розф }}^{\text {очік }} \quad-\quad \text { час } \quad \text { в очікуванні }
$$

розформування;

$t_{\text {розф }}-$ час розформування состава;

$$
t_{\text {нак }}-\text { витрати часу на накопичення }
$$
групи вагонів;

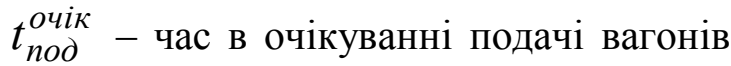
на вантажний пункт;

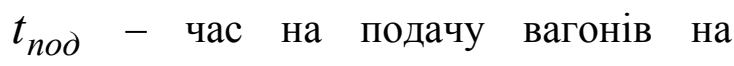
вантажний пункт.
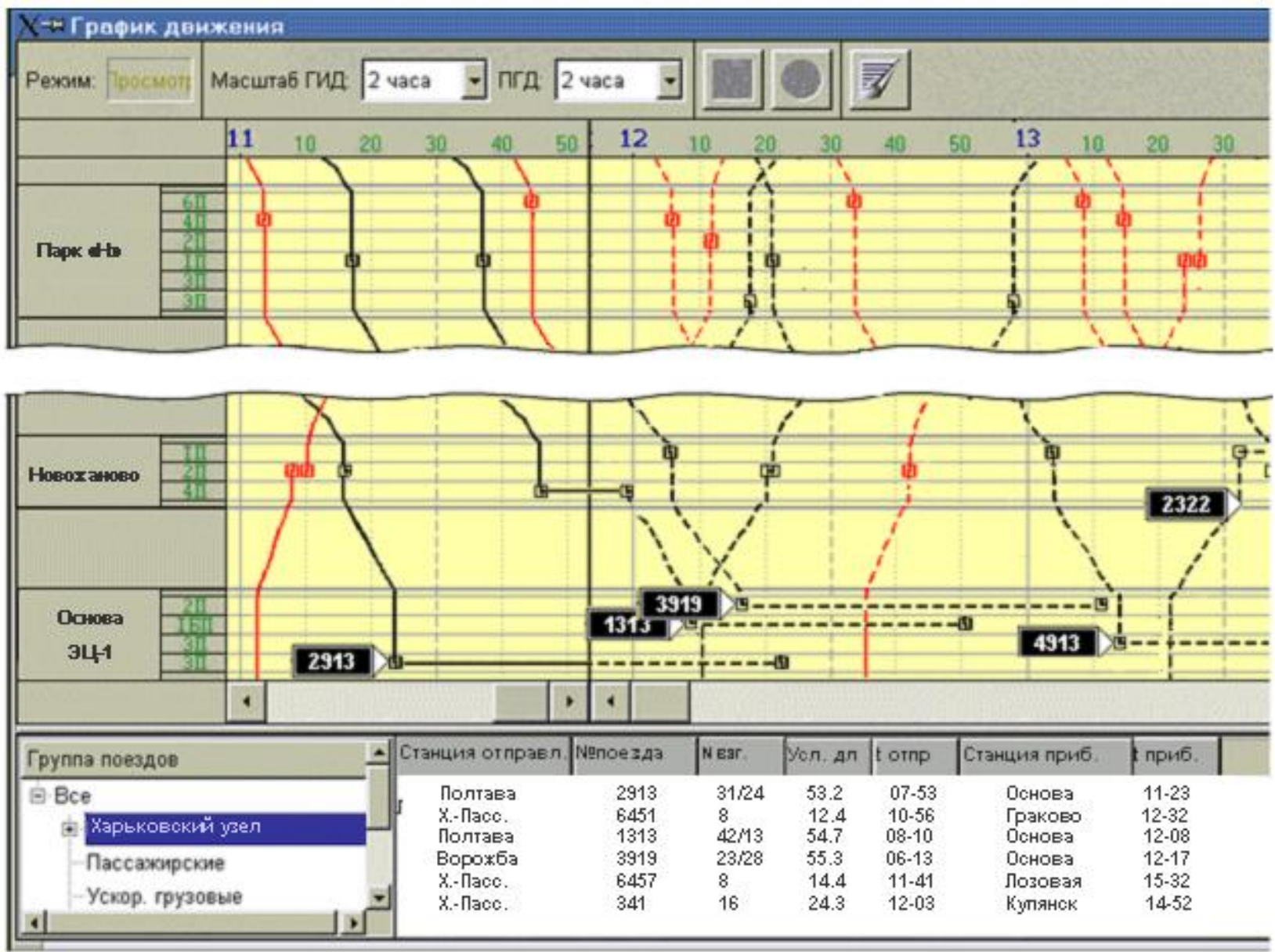

Рис. 2. Оптимальний план проведення поїздів на перегонах залізничного вузла на АРМ ДНЦ із застосуванням МСДЦ «Каскад»

Таким чином, для визначення загальної кількості вагоно-годин в цілому по вузлу на всіх етапах обробки місцевих вагонів застосовано вираз [6]

$$
T_{\text {заг }}=\sum_{k=1}^{n} \sum_{i=1}^{N k} t_{i}^{k}
$$

де $t_{i}^{k}-$ час виконання $i$-ї операції $3 k$-м вантажним вагоном із сукупності вантажних вагонів, що потрапляють у вузол та обробляються в ньому (місцевий, транзитний 3 переробкою та без переробки), год; 
$N_{k}$ - кількість операцій над $k$-м вагоном в межах отриманої технології (технологічні операції та їх очікування);

$n$ - кількість вагонів, над якими виконувалися операції протягом розглянутого періоду.

Для раціональної підв'язки автомобілів до залізничного транспорту слід враховувати інтенсивність надходження вагонів на станцію. Вона розрізняється за періодами доби [3]. Тому середньогодинна інтенсивність надходження автомобілів до складів станції визначається відповідно до ранкових годин роботи транспорту і для решти годин як вираз

$$
\lambda=\frac{N_{a} \gamma_{a}}{T_{p}}
$$

де $N_{a}-$ загальна кількість поїздок автомобілями за добу; $\gamma_{a}-$ частка поїздок автомобілів, які працюють у період доби, що розглядається;

$T_{p}$ - період доби, що розглядається, год.

Висновки. У даній роботі як додаткову функціональну задачу до інформаційно-керуючої системи диспетчерського управління залізничного вузла запропоновано ввести визначення оптимального плану прямування поїздів 3 транзитними та місцевими вагонами в оперативному режимі.

Технологія роботи вузла, що базується на оптимальному плані прямування поїздів, дає змогу більш рівномірно завантажити сортувальну та вантажні станції роботою впродовж доби, зменшити непродуктивні простої рухомого складу, а також підвищити оперативність взаємодії залізничного транспорту 3 вантажовласниками у залізничних вузлах.

\section{Список літератури}

1. Смехов, А.А. Основы транспортной логистики [Текст]: учебник / А.А. Смехов. - М.: Транспорт, 1995. - 197c.

2. Ульяницкий, Е.М. Информационные системы взаимодействия видов транспорта [Текст]: учеб. пособие для вузов ж.-д. трансп. / Е.М. Ульяницкий, А.И. Филоненков, Д.А. Ломаш. - М.: Маршрут, 2005. - 264 с.

3. Лаврухін, О.В. Побудова моделі оптимізації пропуску поїздів на підходах до сортувальної станції [Текст] / О.В. Лаврухін, П.В. Долгополов, Ю.В. Доценко // СхідноЄвропейський журнал передових технологій. - Харків, 2013. - Вип. 64. - С. 15-17.

4. Танаев, В.С. Введение в теорию расписаний [Текст] / В.С. Танаев, В.В. Шкурба; под ред. Д.Б. Юдина. - М.: Наука, 1975. - 256 с.

5. Данько, М.І. Мікропроцесорна диспетчерська централізація «Каскад» [Текст]: навч. посібник / М.І. Данько [та ін.]. - Харків: УкрДАЗТ, 2005. - 176 с

6. Запара, Я.В. Імітаційне моделювання технології роботи залізничного вузла [Текст] / Я.В. Запара // Інформаційно-керуючі системи на залізничному транспорті. - Харків, 2012. Вип. 2. - С.79-86.

Ключові слова: залізничний вузол, синергетична система, диспетчерське керівництво, передаточний поїзд, місцева робота.

\section{Анотаціï}

Як додаткову функціональну задачу до інформаційно-керуючої системи диспетчерського управління залізничного вузла запропоновано ввести оперативне 
визначення оптимального плану прямування поїздів з транзитними та місцевими вагонами. Удосконалена технологія роботи вузла дає змогу більш рівномірно завантажити станції роботою впродовж доби, зменшити непродуктивні простої рухомого складу, а також підвищити оперативність взаємодії залізничного транспорту з вантажовласниками.

В качестве дополнительной функциональной задачи для информационно-управляющей системы диспетчерского управления железнодорожного узла предложено ввести оперативное определение оптимального плана следования поездов с транзитными и местными вагонами. Усовершенствованная технология работы узла позволяет более равномерно загрузить станции работой в течение суток, сократить непродуктивные простои подвижного состава, а также повысить оперативность взаимодействия железнодорожного транспорта с грузовладельцами.

As an additional functional task for awareness-management supervisory system of railway junction prompted the operational definition of the optimal plan of sequence and directions of the local and transit trains. The proposed technology of the railway junction allows to create more uniform load station during the day, reducing unproductive downtime rolling stock, as well as increase the efficiency of interaction of railway transport with clients. 